\title{
The Impact of COVID-19 on Malta and its Economy and Sustainable Strategies**
}

\author{
Grima, Simon ${ }^{1}$, Dalli Gonzi, Rebecca ${ }^{2}$, Thalassinos, Eleftherios ${ }^{3}$
}

\begin{abstract}
A B S T R A C T
The preparedness for outbreaks of pandemics such as the COVID-19 is a major concern for health authorities and leaders as extensive studies in the past have been reported and well documented. However, engaging with the response to an outbreak demands many decisions with enormous implications on a population and its regions. A review of past response mechanisms sheds light on different scenarios to provide an understanding of the challenges that will emerge, depicting trends, changes to GDP and the impact on the economy and employment. With this article we aim to identify and bring to light the challenges faced by Malta during the pandemic we are currently facing - COVID. This will help risk managers and leaders understand the devastating social and economic impact of such disruptions and act proactively to avoid repetition and embarrassments of being unprepared. Moreover we aim to provide an understanding of the expected cascading economic domino effects, which may result from the workforce unavailability, during a pandemic and the mistakes in estimation, if any, that could have been avoided. A desk research study technique was adopted whereby data was collected from existing sources, including government websites, online statistics, published reports, trends and internal data to the local Maltese markets. The COVID-19 phenomena led to new measures being taken worldwide as professionals, leaders, academics and businesses took unpredecented steps to change their business as usual strategies. This in turn brought about various questions and discussions on how islands like Malta controlled their situation.
\end{abstract}

\author{
ART I C LE INFO \\ Keywords: \\ Risk Management; Economy; \\ Malta; Sustainable Strategies; \\ Pandemic; COVID-19. \\ *Corresponding author: \\ Simon.grima@um.edu.mt \\ Article history: \\ Received 3072020 \\ Revised 10072020 \\ Accepted 11072020 \\ **This article is also available \\ on the SSRN Library posted \\ on the 7th July, 2020.
}

\section{INTRODUCTION}

Sands (2019) compares the preparedness for outbreaks of pandemics such as the COVID-19, to the fable of a boiling frog, wherein the frog placed in cold water will remain in the cold water even when the temperature starts to rise gradually to boiling, dooming itself to a catastrophic end. He explains that in paying attention to "stark contrasts and sudden changes", leaders overlook "slow moving changes in the environments that may herald disastrous consequences". He continues to note that in many of the infectious disease outbreaks; it is only once crisis unfolds that leaders, politicians, and influencers race to secure operations and support customers and populations. Decisions were being taken on the fly, without any information and proactive structured procedures of interventions used to identify, monitor, mitigate and respond to these new risks. Kruf (2020), shares some personal thoughts on the outbreak of the COVID-19, and suggests that the action taken by leaders started too late, even though we were aware of an outbreak. He compares this continuity/mitigation action to have started "in the middle of a movie" and explains that leaders seem to have forgotten about it coming. In accordance with the

\footnotetext{
${ }^{1}$ Head of the Department if Insurance, Faculty of Economics Management and Accountancy, University of Malta, Msida, Malta.

2 Department of Construction and Property Management, University of Malta, Msida, Malta.

${ }^{3}$ University of Piraeus, Greece and University of Malta, Msida, Malta
} 
articles by Chua Chow et al. (2002) and Higgins et al. (2018) a virus that evolves into a new unexpected form and that the extent and full implications remain unclear (i.e. the time of the occurrence, location and magnitude are difficult to determine) can be classified as "Unknown Risks /Known Unknowns". Therefore, these scenarios can be simulated on computers to produce unexpected emergent properties and data that make explicit what is now implicit in the rules and the background constrains imposed by the scenario. Furthermore Kruf (2020) highlights that although some believe that we are living in a time of uncertainty, volatility, complexity, and unpredictability, it is not much different from a decade ago. He suggests that the dynamics follow the same patterns, maybe with a different wrapper.

There have been various extensive studies on epidemics, and all these have been reported and well documented. Academics and practitioners have provided scenarios and scenario testing, which are an essential part of every ecosystem and resilience thinking. This suggests that there should be enough scientific knowledge to justify the conclusions on the complexity and predictability of this risk. However, if we fail to act in time or forget to act, this leads to a crisis (Kruf, 2020). Therefore, the Risk Management processes for viruses, which we classify as "Unknown Risks/Known Unknowns”, should be catered for in the business continuity plans of all organizations. Pre-set key indicators should trigger a proactive plan to mitigate all uncertainties that should matter to the objective of the said organization. A pre-set facilities team should trigger the plan for mitigation and/or management. However, not all organizations and world leaders are obliged by regulatory requirements to maintain and test this plan or believe that such proactivity is required. Most are reactive and have political agendas or are disbelievers. This and the day to day agendas may alienate them and populations away from reality. Even where continuity plans are in place, especially in financial services where regulations require that business continuity plans are exhaustive and tested regularly, these sometimes are not complete and miss out the measurement parts, which are not dependent on them but might be influenced by the interrelations with, for example other organizations' decisions or political agendas (Healy et al., 2009).

\section{Literature Review}

According to Santos et al. (2009) disease control experts predicted that "an infection that spreads widely and affects a significant proportion of the population is inevitable". They note that a pandemic endangers the general population, even those who have not been infected. It creates large-scale disruptions in the normal way of life and working sector, leading to further stress with the consequence of fear, illnesses, and mortalities cause by the cascading effects. There are several pandemic viruses, such as the Anthax, the Ebola hemorrhagic fever, but the influenza viruses are the worst fears, since they can mutate and overcome vaccines and migrate quickly, spreading through populations and regions (Santos et al., 2009). Santos et al. (2009) explained that experts predicted that the next pandemic would be widespread and infect between 15 to $35 \%$ of the global population lasting at least four weeks to a maximum of 18 months. They said that this would have multiple waves lasting at least eight weeks with repetitions in the same and different geographic regions, infecting several persons. Health experts project average illness length at two days, with a minimum of one day and maximum of 10 days. Consequently, they anticipated that between 10 to $25 \%$ of the workforce would be absent due to being infected, caring for infected family members or on precautionary quarantine. Moreover, their estimates showed that at least 35\% of "utility (electricity, gas, and water), waste management, mortuary, transport, and healthcare workers would either be infected or develop some other form of medical condition.

The Covid-19 is affecting 209 countries and territories around the world and two international conveyances. As at the time of writing $\left(8^{\text {th }}\right.$ May, 2020), it has already infected over 3.9 million persons worldwide, with more than 271 thousand deaths and countries such as the United States (US), Spain, Italy, Germany, France, China, Iran and the UK being the most hit (Wal- dometer, 2020). Understanding, the challenges faced during this pandemic and highlighting the cascading economic domino effects, which results from workforce unavailability, during a pandemic and the mistakes in estimation, if any, will help risk managers and policy makers in their decisions, who in turn ensure a stronger economy and better wellbeing (Grima, 2018). The choice of Malta for our study follows the ideology that like studies carried out in the past by King (1993), Briguglio (1995), Bezzina et al. 
(2012), Bezzina et al. (2014) and Magri et al. (2019) to use islands as small- scale laboratories for more complex politics, regulations, and policies of larger countries. Malta is a small southern European island state consisting of an archipelago in the Mediterranean Sea. It has a population of circa 475,000 inhabitants with native Maltese comprising most of its inhabitants. Malta covers just over $316 \mathrm{~km} 2$, is a full member of the European Union (EU) and forms part of the Eurozone. Malta is the world's tenth smallest country in area and fifth most densely populated sovereign country. The financial and tourism services sector are a major pillar of Malta's economy and this may be attributed to an advantageous warm climate, numerous recreational areas, architectural and historical monuments, including three UNESCO World Heritage sites, the tax regime, a low cost environment, a well-trained and motivated labour force and a EU-compliant, yet flexible, domicile (Chapman et al., 2004; Malta National Statistics Office, 2019; Finance Malta, 2013; Bezzina et al., 2012; Bezzina et al., 2014).

\section{Gross Domestic Product and Employment}

As noted in the article by Fabri, et al. (2020), a crisis as defined by the Greek work 'krisis' marks a transitional period for a 'decisive turning point'. It is a period where countries and states need to work together to ensure sustainability and embrace opportunities while mitigating catastrophes proactively. Malta, like all other countries has been and will continue to be adversely impacted by this pandemic (COVID-19). Especially for some sectors of the economy the impact is devastating. Although in some sectors of the economy there is no alternative route or limited alternatives some have managed to continue operations using alternative methods and at the same time using protective measure to avoid the spreading of the pandemic. Also, the recent favorable performance of the Maltese economy has allowed room for government intervention. A snapshot of Malta's economic performance of the last 12 years (between 2008 and 2019) in terms of percentage year on year change in Gross Domestic Product (GDP) as compared to the European Un- ion -27 countries (from 2020), the European Union 28 countries (2013- 2020) and similar EU small states (i.e. with a population of less than 3 mil- lion), specifically Estonia, Latvia, Lithuania, Slovenia, Cyprus and Luxembourg, can be seen in Figure 1 and Figure 2 below (Eurostat, 2020).

Figure 1. Real GDP: Year on year percentage change

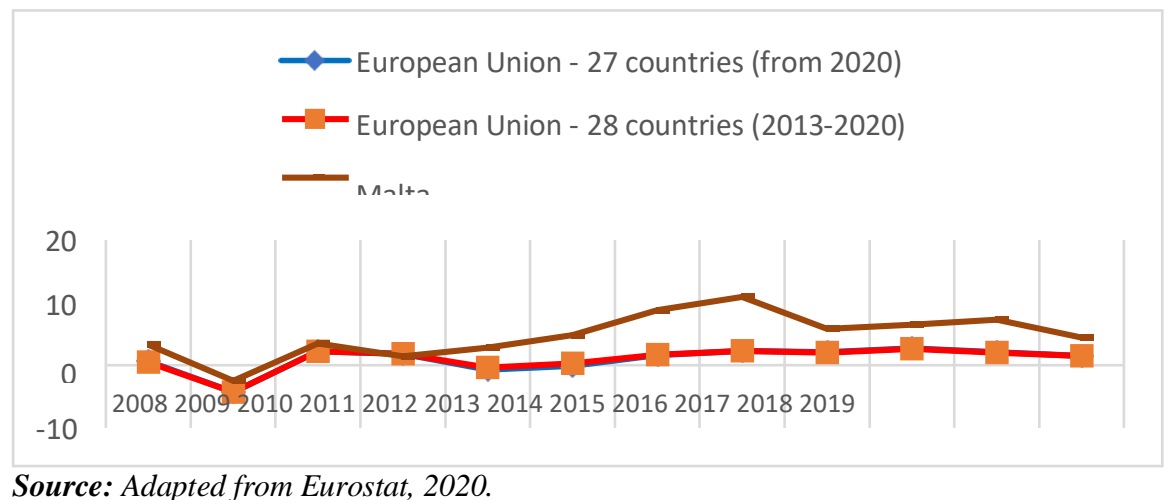

Source: Adapted from Eurostat, 2020.

Figure 2. Real GDP: Year on year percentage change 


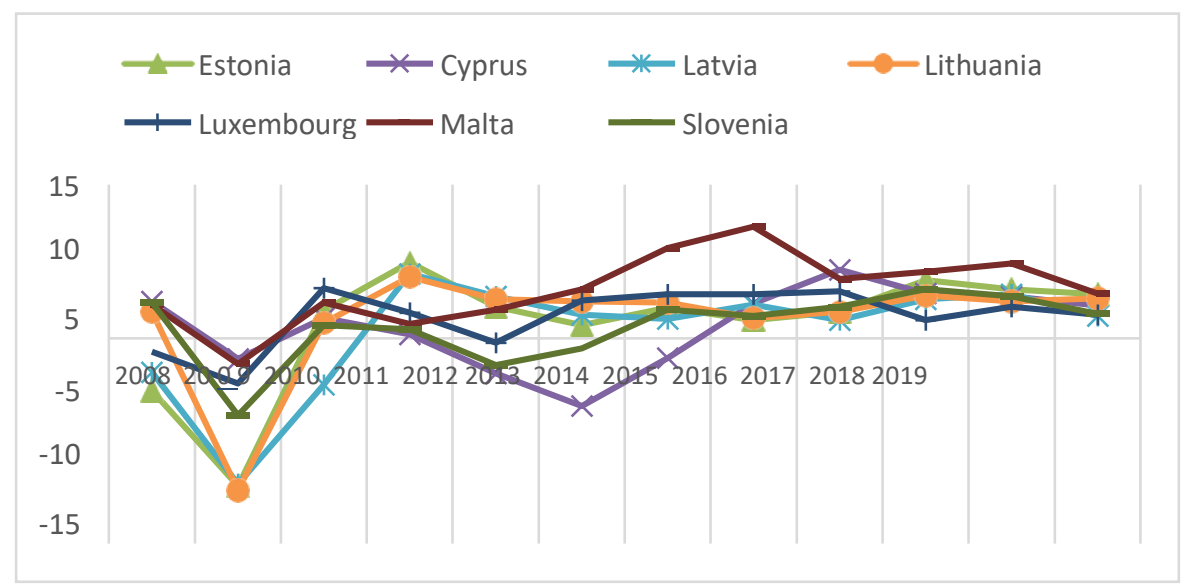

Source: Adapted from Eurostat (2020).

We can note that propelled by a strong service sector, Malta's real growth between 2008 and 2019, even during the financial crisis was above that of the EU 27 and 28 countries, growing at a sustained pace with an increased rate after 2011. Similarly, when compared to other states considered as small, Malta's real GDP growth exceeds all others. This and the fast employment growth impacted the public finances, reversing debt into fiscal surplus with declining debt ratios (Fabri et al., 2020).

According to official data from the World Bank and projections from Trading Economics, the (GDP) in Malta, in 2019, was worth US\$15.10 billion, representing a GDP value of 0.01 percent of the world economy. The expectations are that this will reach US\$15.90 billion by the end of 2020. In the longterm, the Malta GDP is projected to trend around US $\$ 17.50$ billion in 2021 and US\$20.00 billion in 2022 (Trading Economics, 2020; Baldacchino et al., 2020a). The headlines of an article in the Times of Malta of the $14^{\text {th }}$ April, 2020, quotes the International Monetary Fund (IMF) as stating that Malta's economy is likely to shrink by $2.8 \%$ due to the COVID-19 pan- demic, with an expected rebound in 2021 of a strong 7\%. Moreover, in a subheading it also quotes the World Economic Outlook to have projected a 7.5\% decline across the Eurozone (Times of Malta, 2020d; World Economic Outlook, 2020). The article in the times continues to quote the IMF as highlighting the expectation of a rise in 5\% unemployment in 2020 from last figures in 2019 which hovered around the 3.4 percentage mark, which will decrease slightly to $4.4 \%$ in 2021 (Times of Malta, 2020d; World Economic Outlook, 2020). Bassetti (2020), in an article in Focus Economics, corroborates this and notes that Malta together with Netherlands and Germany are the Eurozone countries with the lowest March 2020 unemployment rates of 3.5\%, 2.9\% and 3.5\% respectively. These projections indicate that Malta is expected to suffer a smaller economic impact than those in other countries and regions.

Composition of the Maltese Economy (2019) in Gross Value Added (GVA)

The total \% GVA as at the end of December last year was of $€ 11,715,404,000$ and split up as shown in rounded up \% of GVA in Figure 3 below. The highest percentage contributors to the GVA of Malta are the wholesale and retail trade, repair of motor vehicles and motorcycles, transportation and storage, accommodation and food service activities (20.87\%), followed closely by the Public administration and defense, compulsory social security, education, human health and social work activities (16.8\%), the professional, scientific and technical activities, administrative and support service activities (15.48\%) and arts, entertainment and recreation, repair of household goods and other services (15.26\%). All other sectors contribution was less than 7\% (NSO, 2020a). 
Figure 3. Percentage Gross Value Adding per Sector of the Economy as at December 2019.

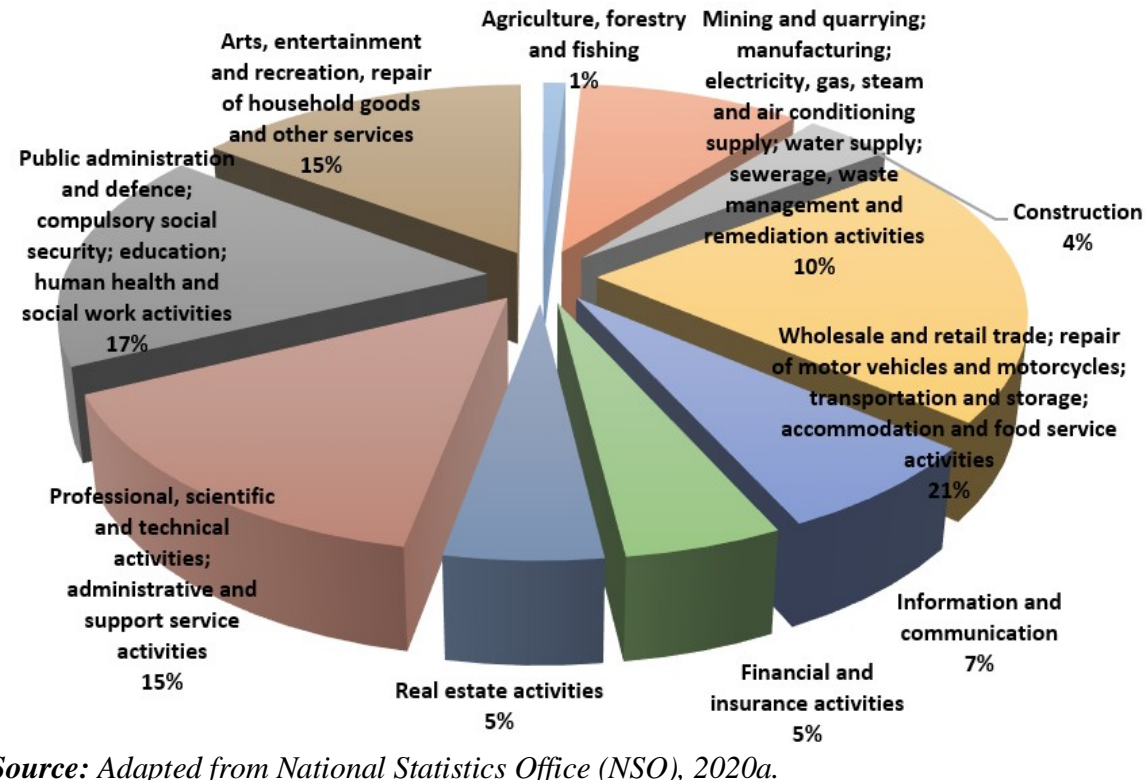

Source: Adapted from National Statistics Office (NSO), $2020 a$.

The total gainfully employed as at October 2019 stood at 223,078 and is split up as shown in Figure 4, with the largest employers being wholesale and retail trade, repair of motor vehicles and motorcycles (12.19\%), mainly the retail and wholesale trade, excluding motor vehicles and motorcycles (90\%) (NSO, 2020b). However, as noted above one needs also to consider the cascading ef- fects of certain industries due to an infectious pandemic onto other sectors as noted by Santos et al. (2009), who noted that a pandemic endangers the general population, even those who have not been infected. It creates large- scale disruptions in the normal way of life and working sector, leading to further stress with the consequence of fear, illnesses, and mortalities cause by the cascading effects (Figure 5).

Figure 4. Full-time employment classified as at October 2019 and by economic activity 


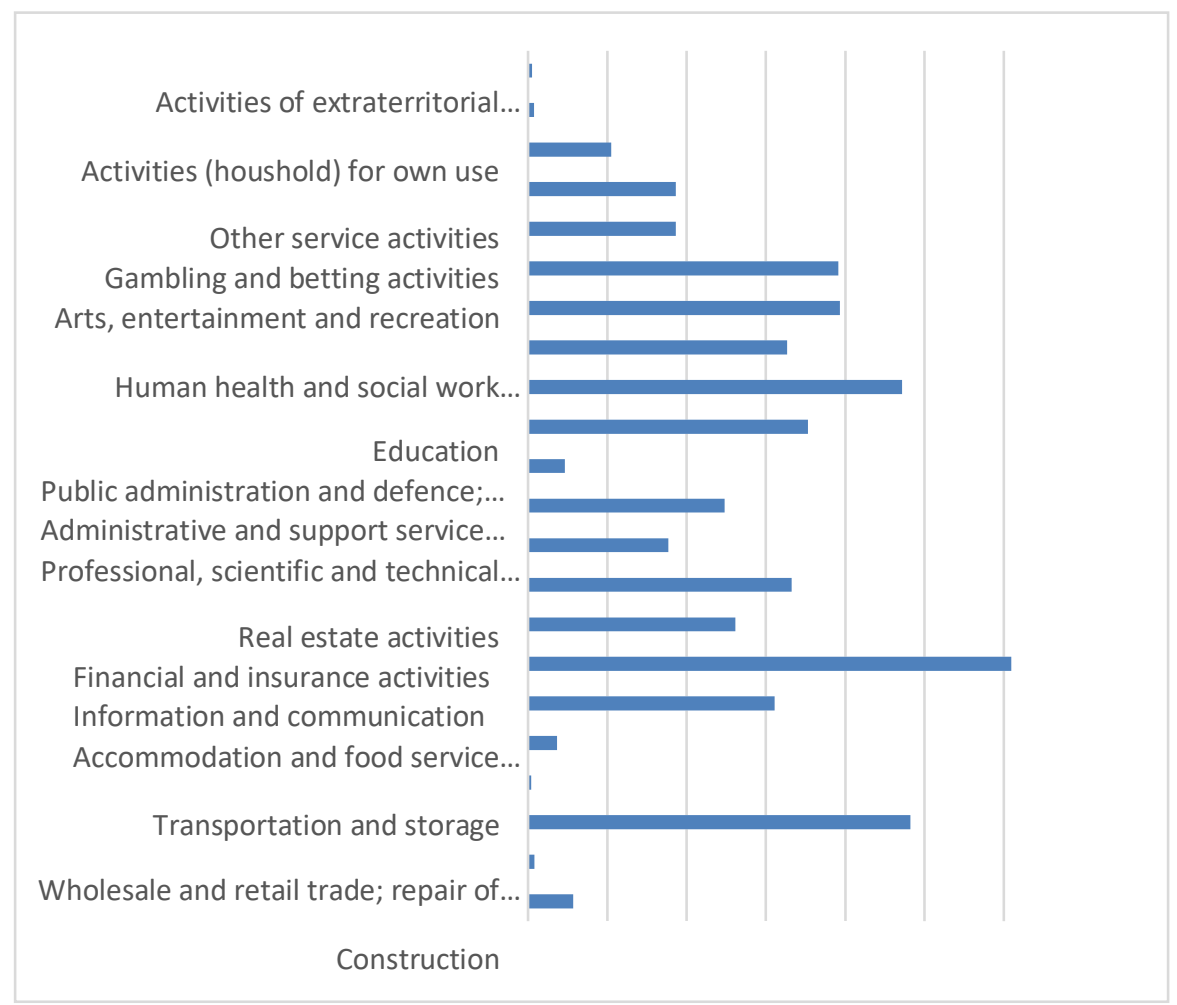

Source: Adapted from National Statistics Office (NSO), 2020 b.

Figure 5. The Overall Problem

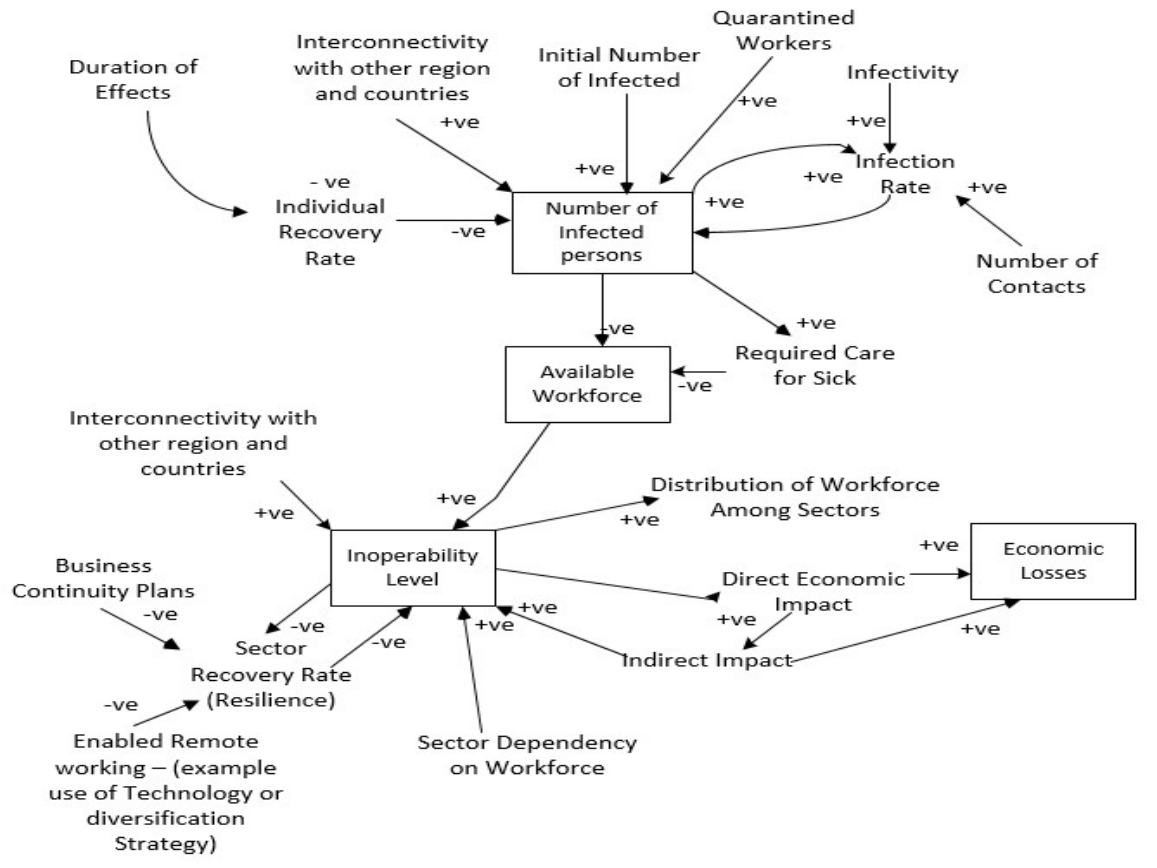

Source: Adopted from Santos et al., (2009)

Figure 5 shows a simplified outline of the overarching problem. That is scenarios of the direct and indirect consequences on the workforce and economic productivity of a virus such as COVID-19 spreading throughout the general populations. Most, if not all economic sectors are dependent in some way (directly or indirectly) on the workforce. Therefore, interdependency is a key component in determining the cascading effects of disruptions on economic productivity. Models can be used to 
model interdependencies across various sectors of a specific regional economy and measure the cascading impact of interdependency amongst sectors of an economy pursuant to a disruption, therefore determining the exposure and enabling an informed decision.

Once a key indicator is flagged, the associated risks are analyzed, and mitigation/ management measures are put in place. Firstly, one needs to de- termine the possible impact of the disruption and the likelihood of it, the preparedness and controls in place to manage/mitigate and ensure continuity with an acceptable remaining residual risk (Kaplan et al., 1981; Baldacchino et al., 2020b).

The efficacy and accuracy of the Risk Management continuity plan will depend highly on the integrity of the data gathering process which depends on the vision and expertise of experts, the integrity of the simulations and tests carried out and historical events (Figure 6).

\section{About the Virus - The Problem Context}

On the 31st December 2019, in Wuhan, Hubei, Province, China there were reports of several pneumonia cases of unknown aetiologia. On the 9th January 2020, the Chinese Centre for disease control reported a new mutated form of coronavirus in the "Severe Acute Respiratory SyndromeCorona- virus (SARS-CoV) phylogenetic clade, as the causative agent of this out- break. This associated infective disease is referred to as a new coronavirus disease 2019 (COVID-19)” (European Centre for Disease Prevention and Control (ECDC), 2020b).

Figure 6. Risk Identification and Management Process

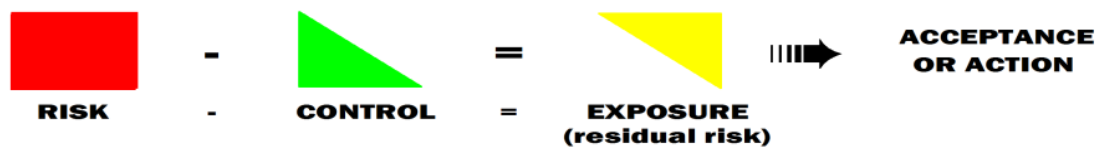

Source: Adopted from Kaplan et al. (1981)

Analyses of cases show that the COVID-19 infection can cause mild symptoms of the disease (i.e. non-pneumonia or mild pneumonia) in about $80 \%$ of cases. Most cases will recover, $14 \%$ of the cases are however more severe, with $6 \%$ being critical ill and will require specialist medical care, which may include mechanical ventilation (Ministero della Salute, 2020). Most of the severe illnesses and deaths occurred among those with other chronic underlying medical conditions, the elderly (European Centre for Disease Prevention and Control (ECDC), 2020a) and those being in long- term care facilities (LTCF) (Tran et al., 2012). Since the COVID-19 is a newly identified virus, no therapeutics or vaccines are yet available, and it is assumed that no form of immunity pre-exists in the communities (European Centre for Disease Prevention and Control (ECDC, 2020a). It is believed that COVID-19 is transmitted from person to person through large respiratory droplets, through inhalation or deposition on mucosal surfaces and through contact with "contaminated fomites and inhalation of aerosols produced during aerosol-generating procedures” (World Health Organization (WHO), 2020).

\section{How it spread in Malta}

Following the worldwide impact of Covid-19 in Malta, on the 24th of January 2020, the Superintendent for Public Health predicted that there was low exposure to the virus due to no direct flights between Malta and China (Calleja and Carabott, 2020). A month later, health authorities announced that all passengers arriving in Malta had to be screened by thermal cameras (Caruana, 2020a). Two thermal scanning devices were installed at Malta International Airport and passengers disembarking from vessels at the Grand Harbour and catamaran terminal were also being scanned. At Mater Dei hospital patients with respiratory problems were being checked for Covid-19 at the same time (ibid). The Ministry for Health, on the 25th of February in- formed any travelers coming from Italy to self-quarantine for 14 days. Furthermore, information was distributed to all citizens that they were not to travel to regions of Italy affected by the outbreak (Ananasso et al., 2020). In the meantime, 
people were being advised to take the necessary precautions for the prevention of respiratory infections (Azzopardi, 2020). The pandemic at the time in Italy, proceeded south with the first case in Palermo. As a result of the outbreak, some firms in Malta requested their staff who had recently returned from Italy to telework and cancelled any non- essential travelling to Italy (Watson, 2020).

Malta reported its first three cases on March 7th, consisting of an Italian family, a 12-year old girl and her parents, who arrived in Malta on the 3rd of March from Rome. They had been self-quarantined since their arrival (Times of Malta, 2020a). As of the 8th March, five hundred and forty tests had been carried and included all those who were in contact with the family (Conneeley, 2020). On the 9th of March, one positive result brought the overall cases to four (Times of Malta, 2020b). Fourth and fifth cases were reported as being Norwegians. On March 11th, the sixth and seventh case was confirmed (Caruana, 2020b) and on March 12th, the eighth and ninth case emerged (Caruana and Carabott, 2020) By March 13th, eight hundred and eighty-nine tests had been carried out and a further three cases were announced (Borg and Cacciattolo, 2020). All cases up until this point were imported from abroad.

By the 14th of March there were eighteen cases in total (Times of Malta, 2020c) and by March 15th a total of twenty-one cases were identified (Arena and Caruana, 2020a; 2020b; 2020c). However, also by this date, the first and second cases had recovered (Cilia, 2020; Bonnici, 2020a). On the 16th of March, the superintendent of public health announced that nine new cases had been recorded bringing the total up to thirty (Azzopardi, 2020b). On March 17th, Maltese authorities confirmed a further eight cases bringing the total up to thirty-eight (Borg, 2020). On March 18th ten new cases were re- ported, including, for the first time, two patients aged over 70. On March 19th, five new cases were reported (Arena and Caruana, 2020b). By the 20th of March, 11 new cases of patients had been reported and included the first Maltese case who developed complications of the infection (TVM Televi- sion Malta, 2020; Arena and Caruana, 2020c). On the 21st of March, nine new cases were reported, and on the 22nd seventeen new cases were re- ported. Ten of the seventeen cases were believed to be related to travel, while the other seven were believed to be locally transmitted. On March 23rd, an- other seventeen new cases were reported (Bonnici, 2020b), and on the 24th, 25th and 26th a total of twentyseven new cases were reported.

The peak of new cases has been reached as at April $11^{\text {th }}$ with 22 new cases and is now hovering between no cases and less than 10 cases per day. The total Coronavirus Cases of infected persons as at the 6th May 2020 stood at 484 with 407 who have since recovered and 5 deaths. This out of 38,337 swab tests carried out on a population approximately 493,559 persons (12.87\%) (Worldometer, 2020). The aim of the health department is to flatten the curve of infected cases to a point where the health department is able to handle the situation (refer to Figure 7) and at the same time put in measures to increase the capacity of health services and protect mainly the vulnerable and older persons, especially those in old persons homes.

In fact, the health authorities have taken measures to segregate and quarantine infected or possible carriers of the viruses at their homes or at different hospitals. Health care personnel have voluntary opted to segregate themselves from their families, by staying in different lodging or remaining quarantined at the respective hospitals or old peoples' homes. Other various measures such as protective equipment etc. have also been provided to health care workers and cleaners who are cleaning and disinfected public places.

The world is generally not prepared for a severe pandemic with naturally devastating effects on health (Studzinski, 2015). Once a key indicator of a virus outbreak is flagged this should trigger a systematic plan to prevent the outbreak from mushrooming nationally and across the globe. Although progress has been made since the response to Ebola in West Africa between 2014 and 2016, experts suggest that the world is still not prepared enough to respond and detect outbreak (World Economic Forum, 2019). Over the past 30 years the frequency and diversity of disease outbreaks has grown steadily (ibid). Increase in deforestation have resulted in new outbreaks as the loss of tree coverage, which has been rising over the past 17 years, and has been linked to 31\% of outbreaks of new and emerging diseases, 
including the Nipah virus, Ebola and Zika (Kessler, 2017). Pandemic experts estimate that pandemics will infect 15-35\% of the world population and last 4 to 18 months with multiple waves (Department of Homeland Security DHS, 2006). Each wave lasts about eight weeks and then repeats itself in the same geographical location.

Figure 7. Figure shows the Flattening the Curve of an outbreak without protective measures versus an outbreak with protective measures.

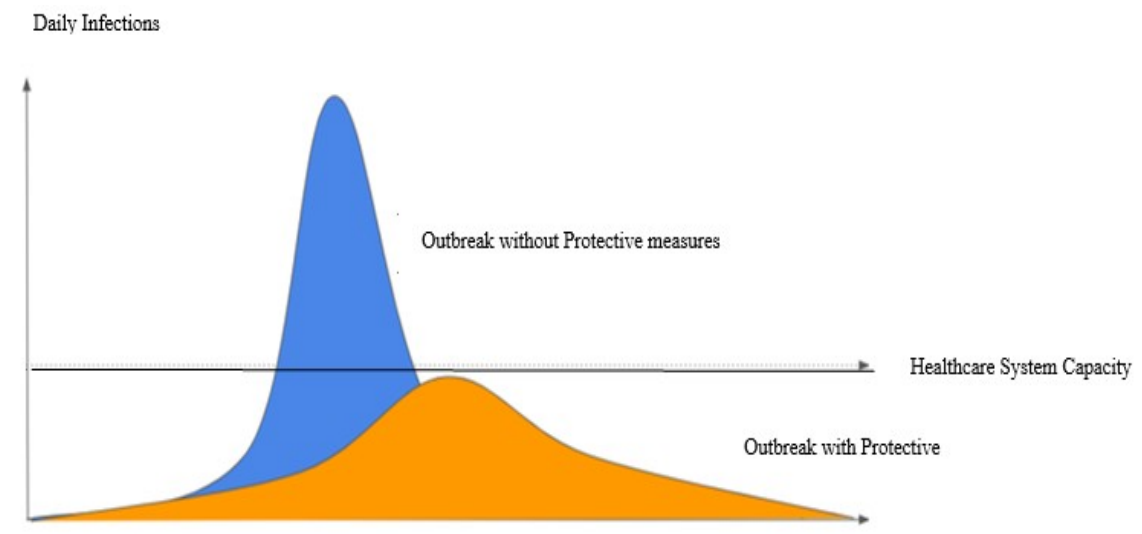

Time since the first case

Source: Adopted from information is beautiful (2020) - (Image credit -Johannes Kal- liauer/CC BY-SA 4.0, 2020)

As at the 9th of April a registered total of twelve thousand, six hundred and sixty-two tests had been carried out. Total cases now amount to one hundred and forty-nine (Worldometer, 2020).

\section{Lessons learnt from past pandemics and disruptions}

The 1889, pandemic which was the earliest pandemic that had been quantitatively studied, researchers found that clinical attack rates were as high as $60 \%$ in age groups ranging from 1 to 60 years, while most influenza deaths were found in older adults. The lack of detailed age- and cause-specific mortality time series data at this time hindered further understanding of the age patterns of deaths associated with this pandemic (Simonsen et al., 2011). In 1918 the world experienced the most severe influenza pandemic in history, with an estimated global death toll of 1-2\% of the global population during 1918-1920 (Murray et al., 2006). Young adults aged 20 to 40 were at extreme risk, while the sparing of seniors did not occur everywhere. The 1918 pandemic signature age pattern slowly reverted to seasonal pattern. During this time, mathematical models played an increasing role in public health decision-making for pandemic influenza and other emerging infectious diseases. The models provided a quantitative framework to evaluate the transmission potential of novel pathogens, consider a variety of epidemic scenarios, and select appropriate public health interventions (Simonsen et al., 2011).

In the moderately severe $1957 \mathrm{~A} / \mathrm{H} 2 \mathrm{~N} 2$ and the milder $1968 \mathrm{~A} / \mathrm{H} 3 \mathrm{~N} 2$ pandemics there was a moderate age shift in mortality towards younger ages, so that younger adults were at far greater risk of death than in a typical sea- son. On the other hand, the mortality risk to the elderly was not that different from a severe seasonal epidemic (Simonsen et al., 1998; Miller et al., 2005). The 2009 pandemic impact was found to be in the range of the 1968 pandemic and more severe than seasonal influenza, using Years of Life Lost (YLL) as a metric, and age standardization (Viboud et al., 2010). The WHO was criticized for having overreacted by recommending vaccination with a monovalent vaccine and other vigorous public health measures. However, considering the information available at hand, a rigorous response to the 2009 pandemic was justified (Viboud et al., 2010; Butler, 2010). Uncertainty surrounds all emerging infectious disease events, and in such conditions, public health officials must make difficult policy decisions (Simonsen et al., 2011). The lessons learned from this pandemic was that it was vital to maintain surveillance efforts and international data sharing in the post-pandemic period so that prevention and control programs could be tailored to the changing epidemiology of post-pandemic 
influenza. A 'Historical Influenza Pandemics: Lessons Learned' Meeting and Workshop was held in May 3-7, 2010 in Copenhagen, Denmark (Simonsen et al., 2011) Plenary sessions highlighted new strategies for spatial and temporal analysis, virus surveillance, and control efforts for the 1889, 1918, 1957, 1968, and 2009) Table 1, influenza pandemics. The implications and results collated from such events means that the global scientific, medical, legal, and political communities are equipped to face future pandemics.

Table 1. Characteristics of the past four influenza pandemics

\begin{tabular}{|c|c|c|c|}
\hline $\begin{array}{l}\text { Pandemic year of } \\
\text { emergence and } \\
\text { common name }\end{array}$ & $\begin{array}{l}\text { Area } \\
\text { origin }\end{array}$ & $\begin{array}{l}\text { Estimated case fa- } \\
\text { tality }\end{array}$ & $\begin{array}{l}\text { Age groups most } \\
\text { affected (36) }\end{array}$ \\
\hline 1918 “Spanish flu” & Unclear & $2-3 \%(37)$ & Young adults \\
\hline $\begin{array}{l}\text { 1957-1958 “Asian } \\
\text { flu” }\end{array}$ & $\begin{array}{l}\text { Southern } \\
\text { China }\end{array}$ & $<0.2 \%$ & All age groups \\
\hline $\begin{array}{l}\text { 1968-1969 "Hong } \\
\text { Kong flu”" }\end{array}$ & $\begin{array}{l}\text { Southern } \\
\text { China }\end{array}$ & $<0.2 \%$ & All ag \\
\hline $\begin{array}{lr}2009 & -2010 \\
\text { enza } & \text { “influ- } \\
2009 " & \\
\end{array}$ & $\begin{array}{l}\text { North Amer- } \\
\text { ica }\end{array}$ & $0.02 \%$ (39) & $\begin{array}{l}\text { Children and } \\
\text { young adults }\end{array}$ \\
\hline
\end{tabular}

Source: Adapted from Pandemic Influenza Risk Management, (2017) A WHO guide to inform and harmonize national and international pandemic preparedness and response. Geneva: World Health Organization.

A lack of effective planning means that the effects of a pandemic will lead to social and economic disruption as is the case with the COVID-19. As is currently happening in Italy (as an example), there is a threat to the continuity of essential services, lower or reduced productivity, distribution difficulties and shortages of supplies and human resources. It is imperative that private and public organizations plan for potential disruption as it is expected to occur (as seen above in historical pandemics) so that business continuity is ensured for all essential services. Also, alternative plans for energy sup- plies, in case of major disruptions, should be evaluated (Pandemic Influenza Risk Management, 2017, Table 1).

\section{Strategies to stop the spread and safeguard businesses}

The risk management challenge to respond to pandemics and control a cascading effect on the workforce is central to maintaining continuity in business operations. Pandemic planning and preparedness in general practice is ultimately a crucial risk management exercise. In the current circum- stances, general good planning at the workplace means employees feel safe to attend their place of work (Nori et al., 2009). Safety is furthermore supported by the recognition of models or steps used to support business survival. A key element in controlling a pandemic is early action (McKinnon, 2006) and for continuity in any business, employees need to know that action is being taken in terms of infection control and business continuity to support productivity. The literature supports four strategies to help stop the spread and support business; these include a) infection control, b) preparedness, c) communication and d) decision-making.

Good infection control: It is a well-known cornerstone of disease management (Nori et al., 2009) which refers to all policies, procedures and activities that aim to prevent or minimize the risk of transmission of infectious diseases. Infection control is critical to any successful strategy. 'Employers must provide a safe working environment for their employees, and must pro- vide such information, instruction, training and supervision as are reasona- bly necessary to ensure that each employee is safe from injury and risks to health'(South Australian Occupational Health and Safety legislation, 1986). Maintaining good infection control helps businesses by ensuring that their facilities are safe to be used during a pandemic. Hand hygiene, social distancing and a lockdown on canteen facilities are all processes undertaken to enhance infection control at the workplace. 
Preparedness: A recent first-of-its-kind comprehensive assessment of health security and related capabilities across 195 countries found fundamental weaknesses around the world: no country is fully prepared to handle an epidemic or pandemic (Nuclear Threat Initiative (NTI), 2019). In the meantime, the world's collective vulnerability to the societal and economic impacts of infectious disease crises appears to be increasing (World Economic Forum, 2019). The Preparedness Index used in the U.S. combines measures from multiple sources and perspectives to offer a broad view of the health protections in place for the nation as a whole and for each U.S. state. The Index identifies strengths as well as gaps in the protections needed to keep people safe and healthy in the face of large-scale public health threats, and it tracks down how these protections vary across the United States and change over time (National Health Security Preparedness Index (NHSPI), 2020). A recommendation was put forward by the International Working Group on Financing Preparedness for the setting up of preparedness indicators by the World Bank for a comprehensive pandemic risk management approach in country specific systemic country diagnostics (Studzinski, 2017). A preparedness Index would help in promoting healthy competition between regions and states and together with business ready programs, business leaders will make preparedness plans to be ready for such hazards (Department of Homeland Security, 2019).

Preparedness for business is available through models such as the DALI model (Dalli Gonzi, 2019; Dalli Gonzi et al., 2019) and FORTE ${ }^{\mathrm{TM}}$ model (Kruf et al., 2019). The DALI Model assists organizations in risk identification and business continuity planning. Through this model, organizations are subjected to eight thematic elements, which as noted in the case for Financial Services firms can be packaged and reduced to four elements, to understand whether management practices can continue to exist and support operational environments, even when unexpected circumstances affect their day-today operations and processes. Similarly, the FORTE model helps in developing a governance structure with the objective of determining the preparedness of both the public and private sectors to ensure resilience to risk events and continuity. The latter is a pioneer model emphasizing that for resilience and continuity, there needs to be an integrated effort between the Public and Private sectors and the community at large (i.e. the leaders and regulators of both the public and private sectors and the community at large.

This pandemic (COVID-19), has shown us more than ever, the importance of integration of these three sectors of and economy. The examples of China and now other countries have shown us that with this kind of inte- gration, the number of new cases and deaths are reduced drastically. In fact, the take home lesson from this pandemic will be the need for integration of all members of this world.

Communication: During this current uncertain scenario and sense of confusion and urgency, the special challenges of communication are empha- sized (WHO, 2005; Centers for Disease Control and Prevention, (CDC) 2002). During a pandemic, a survey of the needs of developing countries conducted by the WHO and other UN agencies showed that many developing countries found communicating at the community level a problem and were requesting support for the planning of behavior change communication at the community level. Clear communication on what the public needed to do to reduce transmission and advice on treatment was the initial requirement. However, as the pandemic progressed, this changed to more complex questions such as vaccination, vaccine safety and the need for continued vigiliance (World Health Organisation/ Unione Nazionale Sindacale Imprendi- tori e Coltivatori di Cosenza United Nations Office for the Coordination of Humanitarian Affairs (WHO/UNSIC/OCHA), 2009).

Communication during a health emergency or crisis often gets bogged down in questions of blame. Who is to take the greater burden of decisions and communicate it, as one part of society affects the other in a domino effect? 'Who is at fault?' 'Then, what action, which means, what damages, what compensation, what restitution?' Risk thus 'becomes a stick for beating authority’ (Douglas, 1992). In relating to business strategies for maintaining continuity, public health questions do arise. These bring on new challenges of conflicting information, as different narratives are created by different power groups; political, environmental, social, youths, education, financial, risk and so on. Businesses benefit when information is shared in real time with strong supporting authorities to compensate for rapid

PAGE 63| Journal of Corporate Governance, Insurance, and Risk Management | 2020, VOL. 7, Series. 1 
changes (such as tax cuts, financial assistance, or changes to regulations). Central to this in- formation exchange is how the entities communicating this information are regarded as trustworthy and those, which were not. Supporting businesses through social media and the internet means that such platforms provide 'al- ternate lines of knowledge circulation,' where websites and blogs also challenged assessments by experts and authorities, presenting a different approach to traditional top-down communication from expert to audience (Briggs, 2009).

The information that business receive during times of crisis will be overwhelming. Therefore, the management of information is critical when fast decisions need to be undertaken. In addition, information management must support the economic case that persuasively reflects on the macrocritical risks and benefits of risk management in a manner that is relevant to the country and private business priorities (Studzinski, 2017).

Decision-making: Public leaders need to recognize they are facing a cri- sis and address it in time (Dalli Gonzi, 2019). If not addressed in time, the scale of the matter or event begins to expand to uncontrollable proportions with resulting impacts on a multitude of sectors. The WHO-China Joint Mission on the Coronavirus Disease shows very clearly that only immediate and decisive public health responses worked to prevent or delay hundreds of thousands of cases in China. For example, decisions over vaccine procurement, travel restrictions, and other public health measures, all have economic and political consequences, and therefore those who communicate about these issues find themselves confronting questions that are not essentially about health but about other aspects of society (Abraham, 2011).

Aside from the impacts on economy and politics, are impacts on busi- nesses. For a business leader to take decisions in the appropriate time one may require situational analysis and risk breakdown based on public man- agement updates, regulations or restrictions that are affecting the country as the crisis grows. Public Risk Management Organization (PRIMO), a think tank organized to host transdisciplinary debates about how to concretize lo- cal management and governance based on the public risks derived from in depth interviews and analyses by world leaders, experts and scientists (Kruf, 2020 ) is an example of bridging the gap between public information to ad- dress business queries and needs. This is a platform that manages public sec- tor information management domain to bring it to the forefront of business leaders for better proactive decision taking as required. This organization emphasizes the need for integration in decision taking between the world leaders and society at large. Business rarely emphasize the risk of infectious disease in their considerations, but if large corporations fully appreciate the commercial threat, they will no longer remain on the sidelines of the efforts to strengthen global health security (World Economic Forum, 2019).

\section{Mandatory Mitigation Measures}

Schools and educational institutions were the first to close as of $13^{\text {th }}$ March 2020) and will remain closed until the end of June, which is the end of the current scholastic year. All students will continue with their learning and studies through online means. With effect from Tuesday 17th March at 11:59pm, all bars (excluding take-away), restaurants (excluding deliveries), gymnasiums, clubs, cinemas, and tombola halls had to close. Closure of Malta International Airport and all passenger flights inbound to Malta were suspended after 23.59hrs of the 20th March 2020. As from the 23 March 2020 at 8am, all shops whereby their principal business relates to the selling of the following services had to close (whether operating in shopping malls and/or elsewhere):

- Clothing

- Sportswear

- Jewellery

- Handbags and leather goods

- Costume jewellery and accessories

- Footwear

PAGE 64| Journal of Corporate Governance, Insurance, and Risk Management | 2020, VOL. 7, Series. 1 
- Non-prescription eyewear

- Perfumeries

- Beauty products

- Haberdasheries

- Soft furnishings

- Household appliances

- Souvenir shops

- Discount stores

- Luggage shops

- Toy shops

- Furniture

- Florists and vaping shops shall be observed

However, these shops could still sell and provide delivery services of their products in the community. Moreover, with effect from this said date and time outlets providing non-essential services, namely hairdressers, barbers, beauticians, spas, nail artists, nail technicians and tattooists, were also to be closed. Also, gatherings of more than four persons is disallowed and subjected to fines if the condition is breached. Fines of $€ 3000$ were imposed each time these new measures were breached (covid19malta, 2020).

\section{Fiscal measures}

As highlighted in the press release PR200520 dated $18^{\text {th }}$ March, 2020, cited on doi.gov.mt, the Prime Minister of Malta, the Minister for Finance and Financial Services and the Minister for the Economy, Investment and Small Business announced the following measures to soften the impact on some sectors of the economy due to the COVID-19 pandemic and support those members of the population that are unable to continue working due to this pandemic. The collective value of this economic package is of circa $€ 1.81$ billion (an amount equal to $12.9 \%$ of Malta's GDP in 2019). A summary of the most salient points as highlighted on this press release and in the government website servizz.gov.mt on April 7th, 2020, are as follows:

Person with Disability Benefit - employed in the in the private sector and following the measures taken by government to mitigate the spreading of the COVID-19 virus from the 8th of March 2020 cannot go to work on medical advice and are not able to work from home, may apply for benefit (a), (b) and (c).

Additional Unemployment Benefit - to workers who after the 8th of March 2020, due to this pandemic have lost their job lose their job in the private sector can apply for (a) to (f) below.

Medical Benefit - to workers who after the 27th of March, 2020, due to this pandemic are not going to work due to an order of the Superintendent of Public Health of Malta, are not allowed to leave their home, are not able to work from home and are not being paid by their employer during their absence from work, may benefit from (a) to (f) below the during their absence from work.

Family Friendly Measures, (Parent Benefit) - to those employed in the private sector with children under 16 years of age, following the measures taken by government to mitigate the spreading of the COVID-19 virus from the 8th of March 2020 cannot go to work on medical advice, are not able to work from home, and who do not work or provide an essential service in a Government department or entity may apply for (a), (b), (c), (d) and (g):

a) a direct payment of $€ 166.15$ per week if you work full-time or $€ 103.85$ per week if you work part-time.

b) the payment of their Social Security Contribution and future con-

PAGE 65| Journal of Corporate Governance, Insurance, and Risk Management | 2020, VOL. 7, Series. 1 
tributory pension rights safeguarded.

c) the entitlement to any Disability Assistances without deductions.

d) an adjustment to the children's allowance (if one is entitled to it) will have its rate adjusted in line with their new income earned up to a ceiling rate of $€ 24.08$ per week per child.

e) any in work benefit will continue to be received without deductions.

f) any supplementary allowances will have the rate adjusted in line with the new income earned up to a ceiling rate of $€ 4.57$ per week for single persons and $€ 12.54$ per week for couples.

g) any Tapering of Benefits received without deductions.

About 12,000 families with children who have both parents/guardians working in the private sector will benefit from this measure.

Tax Deferrals - of dues in respect of income tax, VAT and social security and maternity fund contributions by employers and the self-employed persons for the months of March and April will be postponed. This measure is expected to cost the Government between $€ 400$ million and €700 million.

Bank Guarantees - utilized to support the provision of soft loans or temporary moratoriums on personal and business loans are extended for up to $€ 900$ million. These guarantees are expected to result in an additional access to credit of circa $€ 4.5$ billion, if fully utilized.

Direct Capital Injection - of around €210 (1.5\% GDP) million in the Maltese economy with around $€ 35$ million allocated to the Health Authorities to fight the COVID 19.

Financial Aid, Quarantine Leave - A sum of $€ 350$ will be granted to employers for each employee under quarantine leave. Further Efforts to Assist Businesses by government:

- to cover 2 days of an employee wages per week (based on a maxi- mum wage of $€ 800$ per month) for enterprises suffering from a complete suspension of operations (including providers of accommodation, food and beverage services, language schools and entertainment venues). This is expected to benefit between 20,000 - 44,000 employees

- to cover 2 days of income per week (based on maximum income of $€ 800$ per month) for the self-employed suffering a complete suspension of operations (including providers of accommodation, food and beverage services, language schools and entertainment venues). This is expected to benefit circa 5,700 self-employed persons. Government coverage will increase to 3 days in the case of self-employed individuals who employ others

- to cover 1 day of employee wages per week (based on a maximum wage of $€ 800$ per month) for enterprises whose operations decreased at least by $25 \%$. This is expected to benefit circa 47,500 employees

- to cover 1 day of income per week (based on maximum income of $€ 800$ per month) for the self-employed whose operations decreased by at least $25 \%$. This is expected to benefit circa 9,600 self-employed persons. Government coverage will increase to 2 days in the case of selfemployed individuals who employ others. (doi.mt, 2020).

Housing Subsidies - to those families that benefitted from government housing subsidies and have lost their jobs will be eligible for an increased subsidy.

Third Country Nationals - are not allowed to replace employees dis- missed. Applications for work permits for new third-country nationals will no longer be accepted (an exception will be made for highly skilled workers). However, the Government will seek to assist all third-country nationals who are presently in Malta and have their employment terminated to find an alternative employment. 
Facilitating Teleworking activities - by helping those employers who have invested in teleworking systems. Malta Enterprise is offering to pick up $45 \%$ of the cost of that installation, capped at $€ 500$ per employee and $€ 4,000$ per undertaking.

VAT and tax refunds - process to be expedited.

\section{Conclusion}

World leaders and politicians by nature react only when enticed or triggered by what are considered red flags/key indicators for the Known Un- known only when the issue exists (i.e. when already in a crisis). However, Risk Management is about managing by precaution and proactivity so as not to be in a crisis. Therefore, someone must have got this wrong. Either the measurement or the monitoring was not correctly gauged, or politics and economics prevailed over rationality. Maybe complacency and alienation prevailed due to overreliance on medical advancement, technology, frame- works, and models, which use complicated measurement formulas to deter- mine when and how to trigger reaction.

The COVID-19 opens the world of professionals, leaders and academics to various questions and discussions on for example, how could a country like Malta, which is an Island have stopped rather than controlled the situation? Could leaders have taken the decision to close borders or impose quarantines on imported possible COVID-19 infected persons earlier? How could Italy and Spain allow mass gatherings to watch a football match in the Bergamo area?

COVID-19 is classified as Known unknown and should trigger immediate Red flags and drastic approaches. Approaches, which our ancestors have taken in the past for other virus outbreaks and without the technological knowledge and communication systems, we have today.

Although, Malta so far seem to be controlling the outbreak from hitting too hard at one go, the plans by the World Health Organization (WHO), whom the Maltese Health Authorities rightly follow, seem reactive (Disaster Recovery) based at a first instance on a partially reactive mentality of half measures (if we hit a certain point we react) and one can only hope that the numbers do not spike.

We say partially reactive, since our belief is that the Red flag raised by the WHO, might have been raised late maybe due to incorrect information provided at the start of the outbreak. Should a recalibration of the Red Flag be done?

In fact, in an article by Qui (2020), notes that Wuhan-based virologist Shi Zhengli identified several deadly SARS-like viruses in bat caves, and warned that there are more. She further notes that many scientists suggest that we should be more proactive and not respond only when deadly pathogens arise. We need to take preventive action, by a identifying them and developing better diagnostic tests. The focus should be on "high-risk viral groups in mammals prone to coronavirus infections, such as bats, rodents, badgers, civets, pangolins and nonhuman primates with developing countries in the tropics, where wildlife diversity is greatest, should be the front line of this battle against viruses"

She continues to note that only once, these potential pathogens are mapped out, can regularly check for possible infections be analyzed and an outbreak can be caught before it turns into an epidemic, saving economies from epidemic costs (Qui, 2020)

However, the COVID -19 pandemic will surely serve a purpose to:

1) change the world and connect the world political powers and decision makers to the community - the government's power in decision making on risks will change,

2) to determine a set of new risks, which are now emerging and have been missed in our continuity plans, and

3) to learn from the experience of other countries such as Korea and Taiwan, who responded

PAGE 67| Journal of Corporate Governance, Insurance, and Risk Management | 2020, VOL. 7, Series. 1 
proactively and successfully. These highlight the importance of democracies rather than those run by populist or authoritarian leaders (Menon, 2020).

As Menon, (2020) notes, the COVID-19 is proof of our interdependence. However, in all polities, there is already a turning inward, a search for autonomy and control of one's own fate. We are headed for a poorer, meaner, and smaller world. Finally, there are signs of hope and good sense. India took the initiative to convene a video conference of all South Asian leaders to craft a common regional response to the threat. If the pandemic shocks us into recognizing our real interest in cooperating multilaterally on the big global issues facing us, it will have served a useful purpose.

\section{References}

Abraham T. (2011). Lessons from the pandemic: the need for new tools for risk and outbreak communication, Emerging Health Threats Journal, 4:1, 7160, doi: 10.3402/ ehtj.v4i0.7160

Ananasso A., de Stabile E., Gagliardi, G., Matteucci P (2020) 'Coronavirus in Italia: aggiornamento ora per ora'. la Repubblica 22 February. Retrieved from:

https://www.repubblica.it/cronaca/2020/02/22/news/coronavirus_in_italia_a ggiornamento_ora_per_ora249241616/?refresh_ce.(28.03.2020)

Arena, J., Caruana C. (2020a). 'Three new coronavirus cases in Malta’ Times of Malta. 15 March, Retrived from: https://timesofmalta.com/articles/view/three-new-coronavirus-cases-in- malta.778310. (27.03.2020)

Arena, J., Caruana C. (2020b). 'Watch: Authorities warn coronavirus peak 'yet to come', five new cases reported' Times of Malta. 19 March, Retrieved from:

https://timesofmalta.com/articles/view/watch-health-authorities-briefing-on- latest-developments.779297 (27.03.2020)

Arena, J., Caruana C. (2020c). 'Coronavirus: 11 new cases including man with health complications' Times of Malta. 19 March, Retrieved from: https://timesofmalta.com/articles/view/watch-dailycoronavirus- update.779510 (27.03.2020)

Bassetti, M. (2020). Eurozone: Unemployment rate ticks up in March as coronavirus blow starts to bite. FOCUSECONOMICS. Economics Retrieved from: Forecasts from the world's Leading Economists. April 30, 2020. Retrieved: https://www.focuseconomics.com/countries/eurozone/news/unemployment/unemployment- rate-ticks-up-in-march-ascoronavirus-blow-starts. (27.03.2020)

Baldacchino, P., Camilleri, A., Schembri, B., Grima, S., Thalassinos, E. (2020a). Performance Evaluation of the Board of Directors in Listed Companies: A Small State perspective. International Journal of Finance, Insurance and Risk Management. X (1), 2020.99-119

Baldacchino, P., Tabone, N., Schembri, Camilleri, J., Grima, S. (2020b). An Analysis of the Board of Directors Composition: The Case of Maltese Listed Companies. International Journal of Finance, Insurance and Risk Management. X(1), 2020.99-119

Bonnici, J. (2020a). 'The Second Person Recovers From The COVID-19 Coronavirus In Malta', Lovinmalta, 15 March, Retrieved from:: https://lovinmalta.com/news/the-second-person-recovers-fromthe-covid- 19-coronavirus-in-malta/ (28.03.2020)

Bonnici, J. (2020b). 'WATCH: There Are Over 100 COVID-19 Cases In Malta After 17 New Patients Confirmed', Lovinmalta, 15 March, Retrieved from: https://lovinmalta.com/news/watch-there-areover-100-covid-19-cases-in- malta-after-17-new-patients-confirmed/(28.03.2020)

PAGE 68| Journal of Corporate Governance, Insurance, and Risk Management | 2020, VOL. 7, Series. 1 
Borg, B. (2020). 'As it happened: New coronavirus cases, as companies count their losses' Times of Malta.,17 March. Retrived from: https://timesofmalta.com/articles/view/coronavirus-restrictionsupped-as- malta-battles-to-slow-virus.778691. (28.03.2020)

Borg, B., Cacciattolo, D. (2020). 'As it happened: New coronavirus travel rules as cases rise to twelve'. Times of Malta,13 March, Retrieved from: https://timesofmalta.com/articles/view/live-blogcoronavirus-updates-12- cases-in-malta.777782. (27.03.2020)

Bezzina, F. and Grima, S. (2012). "Exploring factors affecting the proper use of derivatives: an empirical study with active users and controllers of derivatives”, Managerial Finance, 38(4), pp. 414434.

Bezzina, F., Grima, S., \& Mamo, J., (2014). Risk Management practices adopted by financial firms in Malta, Managerial Finance, (Emerald Group Publishing Ltd.) 40(6),pp 587-612.

Briggs CL, Nichter M. (2009). Biocommunicability and the biopolitics of pandemic threats. Med Anthropol. 28(3):189_98.

Briguglio, L. 1995. “Small island developing states and their economic vulnerabilities”, World Development, 23(9), pp. 1615-1632.

Caruana, C. (2020a) 'Coronavirus: Thermal screening kicks off in Malta as Italy death toll rises'. Times of Malta, 24 February. Retrived from: https://timesofmalta.com/articles/view/coronavirusthermal-screening- kicks-off-in-malta-as-italy-death-toll.773360 (30.03.2020)

Caruana, C. (2020b). 'Coronavirus patients six and seven confirmed'. Times of Malta, 11 March Retrieved from: https://timesofmalta.com/articles/view/sixth-coronavirus-case- confirmed.777254 (30.03.2020).

Caruana, C., Carabott, S. (2020). 'Eight and ninth coronavirus cases recorded in Malta'. Times of Malta, 12 March, Retrived from: https://timesofmalta.com/articles/view/eighth-and-ninth-coronaviruscases- recorded-in-malta.777491 (29.03.2020)

CDC. Centers for Disease Control and Prevention (CDC). (2002). Crisis and emergency risk communication. Atlanta: Centres for Disease Control and Protection; p. 267

Chua Chow, C., Sarin, R.K. 2002. Known, Unknown, and Unknowable Uncertainties. Theory and Decision 52, 127-138 (2002). doi: https://doi.org/10.1023/A:1015544715608.

Cilia, J. (2020). 'The First person has recovered from The Coronavirus in Malta', Lovinmalta, 13 March, Retrvied from: https://lovinmalta.com/news/the- first-person-has-recovered-from-thecoronavirus-in-malta/ (28.03.2020)

Conneely, V. (2020). 'Coronavirus: fake claims on social media over case at Gzira hotel' Times of Malta, 9 March. Retrived from: https://timesofmalta.com/articles/view/coronavirus-fake-claims-onsocial- media-over-case-at-sliema-hotel.776849 (27.03.2020)

COVID-19 info page. (2020). Latest News- View the latest updates. 5th April, 2020. https://covid19malta.info/

Department of Homeland Security (DHS). (2006) Pandemic influenza: Preparedness, response, and recovery (guide for critical infrastructure and key resources). Retrived from:

www.flu.gov/professional/pdf/cikrpandemicinfluenzaguide.pdf. Accessed on 3 March, 2020

Douglas M. (1992)Risk and blame: essays in cultural theory. London: Routledge

Dalli Gonzi, R. (2019). Change and Continuity Management in the Public Sector:The DALI Model for Effective Decision Making. Emerald Publishing Limited

PAGE 69| Journal of Corporate Governance, Insurance, and Risk Management | 2020, VOL. 7, Series. 1 
Dalli Gonzi, R., Grima, S., Kizilkaya, M. and Spiteri, J. (2019). The Dali Model in Risk-Management Practice: The Case of Financial Services Firms. Journal of Risk and Financial Management. MDPI. pp $1-15$.

Doi.gov.mt. (2020). PR200520, Press release from the prime Minister - financial packet of $€ 1.81$ billion support the economy. Retrieved: https://www.gov.mt/en/Government/DOI/Press\%20Releases/Pages/2020/M arch/18/pr200520.aspx (18.03.2020)

European Centre for Disease Prevention and Control (ECDC). (2020a). Rapid risk assessment: Outbreak of novel coronavirus disease 2019 (COVID-19): increased transmission globally - sixth update 2020

European Centre for Disease Prevention and Control (ECDC). (2020b). Infection prevention and Control for COVID-19 in healthcare settings. March 2020. ECDC Technical Report. ECDC: Stockholm

Eurostat. (2020).Real GDP growth rate - volume Retrieved:

https://ec.europa.eu/eurostat/databrowser/view/tec00115/CustomView_1/ta ble?lang=en (29.03.2020)

Fabri, S., Cassar, V., Fabri JP, Fenech G, Spiteri, J. (2020). Agile. Perspectives on Malta’s economy post COVID-19, Seed. ISBN 978-99957-1-723-0.

Grima, S., Spiteri, V.,J., Mihajlo, J., Camilleri, C., Buttigieg, C.,S. 2018. High Out- of-Pocket Health Spending in Countries with a Mediterranean Connection. Frontiers in Public Health,6:145. Health Economics. April 2018. doi: 10.3389/fpubh.2018.00145

Healy, A., Malhotra, N. 2009. Myopic Voters and Natural Disaster Policy. American Political Science Review. Vol.103, No.3 August 2009 doi:10.1017/S0003055409990104. https://www.primoeurope.eu/wp- content/uploads/2016/05/healy_malhotra_2009.pdf

Higgins, D. and Perera, T. (2018), "Advancing real estate decision making: understanding known, unknown and unknowable risks", International Journal of Building Pathology and Adaptation, Vol. 36 No. 4, pp. 373- 384. Doi: https://doi.org/10.1108/IJBPA-01-2018-0006

Information is Beautiful. (2020). 'Flattening the Curve'. COVID-19 \#CoronaVirus Infographic Data pack (2020). Retrived from: https://informationisbeautiful.net/visualizations/covid-19-coronavirusinfographic-datapack/. (23.03.2020)

Kalliauer, J. (2020). Creative Commons (CC) BY-SA 4.0, 2020

Kaplan S, Garrick BJ. (1981). On the quantitative definition of risk. Risk Analysis, 1981; 1(1):11-27.

Kessler, R. (2017). “What Exactly Is Deforestation Doing to Our Planet?”, EcoHealth Alliance, Retrieved from: https://www.ecohealthalliance.org/2017/11/deforestation-impact-planet. (28.03.2020)

Kruf, J.P., Grima, S., Kzilkaya, M.,Spiteri, J.,Slob, W. and O’Dea, J. (2019). The PRIMO FORTE Framework for Good Governance in Public, Private and Civic Organisations: An Analysis on Small EU States. European Research Studies Journal. XXII,(4), pp. 15-34.

Magri, A., Farrugia, A., Valetta, F. and Grima, S. (2019). An Analysis of the Risk Factors Determining Motor Insurance Premium in a Small Island State: The Case of Malta. International Journal of Finance, Insurance and Risk Management IX (1-2). Pp. 63-85.

McKinnon M. Clinical scenarios. Med J Aust 2006;185:S32-4. 
Menon, S. (2020).This Pandemic Can Serve a Useful Purpose .FP. Analysis: How the World Will Look After the Coronavirus Pandemic share.20th March, 2020. Retrieved from: https://foreignpolicy.com/2020/03/20/world-order- after-coroanvirus-pandemic/ (23.03.2020)

Ministero della Salute. (2020). Covid-19 - Situazione nel mondo [updated 10 March 2020; cited 2020 11 March]. Retrived from: http://www.salute.gov.it/portale/nuovocoronavirus/dettaglioContenutiNuov oCoronavirus.jsp?lingua=italiano \&id=5338\&area=nuovoCoronavirus\&menu=vuoto.

Murray CJ, Lopez AD, Chin B, Feehan D, Hill KH. (2006). Estimation of potential global pandemic influenza mortality on the basis of vital registry data fromthe 1918-20 pandemic: a quantitative analysis. Lancet 368.December (9554)):2211-8

National Health Security Preparedness Index (NHSPI). (2020). Prepared. https://nhspi.org/

National Statistics Office (NSO). (2020a).

https://nso.gov.mt/en/News_Releases/Documents/2020/02/News2020_034.pdf

National Statistics Office (NSO). (2020b).

https://nso.gov.mt/en/News_Releases/View_by_Unit/Unit_C2/Labour_Mar

ket_Statistics/Pages/Registered-Employment.aspx

Nori, R., Piccardi, L., Maialetti, A., Goro, M., Rossetti, A., Argento, O., \& Guariglia, C. (2018). No Gender Differences in Egocentric and Allocentric Environmental Transformation After Compensating for Male Advantage by Manipulating Familiarity. Frontiers in neuroscience, 12, 204. doi: https://doi.org/10.3389/fnins.2018.00204

Nuclear Threat Initiative NTI). (2019). "Global Health Security Index: Inaugural Global Health Security Index Finds No Country Is Prepared for Epidemics or Pandemics”. NTI. Press Release, 24 October 2019. Retrieved from: https:// www.nti.org/newsroom/news/inaugural-global-health-securityindex-finds-no-country-prepared-epidemics-or-pandemics/ (30.03.2020)

Pandemic Influenza Risk Management. (2017). A WHO guide to inform and harmonize national and international pandemic preparedness and response. Geneva: World Health Organization

Times of Malta. (2020a). 'Malta's first corona virus cases are girl and parents'.

Times of Malta. 7 March, Retrieved from:

https://web.archive.org/web/20200307233527/https:/timesofmalta.com/arti cles/view/first-coronaviruscase-reported-in-malta.776288 Accessed 29th March 2020

Times of Malta., (2020b). Coronavirus: Fourth case in Malta confirmed.’ Times of Malta,9 March. Retrieved from: https://timesofmalta.com/articles/view/coronavirus-fourth-case-in-maltaconfirmed.776951. Accessed: 26th March, 2020

Times of Malta. (2020c). Five new coronavirus cases, taking Malta's total to 18.' Times of Malta, 14 March. Retrieved from: https://timesofmalta.com/articles/view/five-new-coronavirus-cases-taking- maltastotal-to-18.778007 (27.03.2020)

Times of Malta. (2020d). A visual guide to the spread of coronavirus in Malta. Six charts that explain the COVID-19 outbreak. Retrieved from: https://timesofmalta.com/articles/view/a-visual-guide-to-thespread-of- coronavirus-in-malta.782636 (29.03.2020)

Times of Malta, (2020d). Malta's economy likely to shrink by 2.8\%, but will rebound in 2021 - IMF. April 14, 2020. Retrieved from https://timesofmalta.com/articles/view/maltas-economy-likely-to-shrinkby- 28-this-year-imf.785633 (27.03.2020) 
Trading Economics, (2020). Malta GDP1970-2019 Data.2020-2022 Forecast.

https://tradingeconomics.com/malta/gdp

Tran K, Cimon K, Severn M, Pessoa-Silva CL, Conly J. (2012). Aerosol generating procedures and risk of transmission of acute respiratory infections to healthcare workers: a systematic review. PLoS One. 2012;7(4):e35797-e.

TVM. (2020). ‘11-il każ ġdid ta' COVID-19 f'pajjiżna - l-ewwel każ minn Ghawdex’ TVM Television Malta, 20 March, Retrieved from: https://www.tvm.com.mt/mt/news/11-il-kaz-gdid-tacovid-19-fpajjizna-l- ewwel-kaz-minn-ghawdex/. (23.03.2020)

Sands, P. (2019). Outbreak Readiness and Business Impact Protecting Lives and Livelihoods across the Global Economy. White Paper. World Economic Forum. In collaboration with Harvard Health Insitute. January 2019. Page 5.

Santos, J.R., Orsi, M.J., and Bond, E, J. (2009). Pandemic Recovery Analysis Using the Dynamic Inoperability Input-output Model. Risk Analysis, Vol.29, No.12, 2009. doi: $\underline{10.1111 / \mathrm{j} .1539-}$ 6924.2009.01328.x

Serviz.com.mt. (2020). Inclusion, equality and social welfare. Retrieved from: (https://www.servizz.gov.mt/en/Pages/Inclusion_-Equality-and-Social- Welfare/COVID-19-SocialMeasures/Socia Measures/WEB05171/default.aspx (29.03.2020)

Simonsen, L., Clarke, M.J., Schonberger, L.B., Arden, N.H., Cox, N.J., Fukuda, K. (1998). Pandemicversus epidemic influenza mortality: a pattern of changing age distribution. JInfect Dis.178. July (1)53-60.

Simonsen, L., Viboud, C., Chowell, G., Andreasen, V., Olson, D., Parekh, V., Molbak, K., Miller, M. (2011). The need for interdisciplinary studies of historic pandemics, Vaccine. 29S. B1- B5

South Australian Occupational Health and Safety legislation. (1986).

OCCUPATIONAL HEALTH, SAFETY AND WELFARE ACT 1986.

Retrieved from: https://www.legislation.sa.gov.au/LZ/C/A/OCCUPATIONAL\%20HEALT H\%20SAFETY\%20AND\%20WELFARE\%20ACT\%201986/2002.05.03/19 86.125.PDF (23.03.2020)

Studzinski, N.G. (2017). Comprehensive Pandemic Risk Management: A Systems Approach World Economic Forum, Global Agenda Council on Complex Systems

Qui, J. (2020). How China’s ‘Bat Woman’ Hunted Down Viruses from SARS to the New Coronavirus. Scientific American. Public Health. April 27, 2020. Retrieved from: https://www.scientificamerican.com/article/how-chinas- bat-woman-hunted-down-viruses-from-sarsto-the-new- coronavirus1/?amp=true (23.03.2020)

Viboud, C., Miller, M., Olson, D., Osterholm, M., Simonsen, L. (2010).

Preliminary estimatesof mortality and years of life lost associated with the 2009 A/H1N1 pandemic in the US and comparison with past influenza seasons. PLoS Current ;2:RRN1153.

Waldometer, 2020. Coronavirus. 7th May, (2020).

https://www.worldometers.info/coronavirus/country/malta/

Watson, G. (2020). 'Coronavirus: Deloitte Malta asks staff returning from Italy to work from home' TimesofMalta, 25 February. Retrieved from https://timesofmalta.com/articles/view/deloitte-maltaasks-staff-returning- from-italy-to-work-from-home.773615. (20.03.2020) 
World Health Organisation (WHO). (2020). Report of the WHO-China Joint Mission on Coronavirus Disease 2019 (COVID-19) 2020 [cited 202011 March]. Retrieved from:

https://www.who.int/docs/default-source/coronaviruse/who-china-joint-mission-on-covid-19-final-report.pdf. (04.04.2020)

World Health Organisation (WHO). 2005. WHO outbreak communications guidelines. Geneva:

World Health Organization.

World Health Organisation/ Unione Nazionale Sindacale Imprenditori e Coltivatori di Cosenza United Nations Office for the Coordination of Humanitarian Affairs (WHO/UNSIC/OCHA). (2009). Urgent support for developing countries' responses to the H1N1 influenza pandemic.

World Economic Forum. (2019). "Outbreak Readiness and Business Impact Protecting Lives and Livelihoods across the Global Economy”. White Paper, in collaboration with Harvard Global Health Institute. Retrieved from: https://www. weforum.org/whitepapers/outbreak-readiness-and- businessimpact-protecting-lives-and-livelihoods-across-the-global- economy (04.04.2020)

World Economic Outlook. (2020). World Economic outlook reports. World Economic Outlook, April 2020: The Great Lockdown. April 2020. Retrieved from https://www.imf.org/en/Publications/WEO/Issues/2020/04/14/weo-april- 2020 (04.04.2020) 